\title{
Fouling community dominated by Metridium senile (Cnidaria: Anthozoa: Actiniaria) in Bahía San Julián (southern Patagonia, Argentina)
}

\author{
Juan Pablo Martin ${ }^{1}$, Agustín Garese ${ }^{2}$, Alicia Sar ${ }^{1}$, Fabián H. Acuña ${ }^{2}$ \\ ${ }^{1}$ Instituto de Ciencias del Ambiente, Sustentabilidad y Recursos Naturales (ICASUR), Unidad Académica San Julián, \\ Universidad Nacional de la Patagonia Austral, Colón y Sargento Cabral, (9310) Puerto San Julián, Santa Cruz, Argentina. \\ E-mail: martin_jpablo@yahoo.com.ar \\ ${ }^{2}$ Instituto de Investigaciones Marinas y Costeras (IIMyC), Facultad de Ciencias Exactas y Naturales - CONICET, \\ Universidad Nacional de Mar del Plata, Funes 3250, (7600) Mar del Plata, Argentina.
}

\begin{abstract}
Summary: The objective of this study is to provide information about a harbour-fouling community dominated by Metridium senile in southern Patagonia. Several steel tubes from the wharf of Puerto San Julián were extracted to perform repair tasks, allowing the attached benthic community to be studied. Sampling was conducted at three levels: lower intertidal, 3-4 $\mathrm{m}$ depth and 6-7 m depth. In the lower intertidal, M. senile had a relative abundance of $43 \%$, the most abundant accompanying species being Perumytilus purpuratus, Mytilus edulis platensis and Aulacomya atra atra. At subtidal level, the anemone showed relative abundances of $64 \%$ and $65 \%$, and was accompanied by Monocorophium insidiosum at 3-4 m depth and by polychaetes of families Sabellidae and Syllidae at 6-7 $\mathrm{m}$ at depth. In the lower intertidal, epibiosis was more frequent on $P$. purpuratus, A. atra atra and M. edulis platensis, while in the subtidal, the richness of substrate-organisms increased significantly and the anemone was fixed to A. atra atra, M. edulis platensis, Paramolgula gregaria, Crepipatella dilatata, Austromegabalanus psittacus, Hiatella arctica, Polyzoa opuntia, Pyura sp. and Sabellidae tubes. The ability of M. senile to settle on many different organisms, along with other strategies, makes it a colonizer able to displace other species that could compete with it for substratum. Given the cosmopolitan nature of $M$. senile, the fact that this species has not been previously reported in the coastal zone of the region, and the results of our study, we discuss the possibility that this sea anemone is an invasive alien species in southern Patagonia, or at least a cryptogenic species.
\end{abstract}

Keywords: biofouling; benthic communities; Actiniaria; Metridiidae; epibiosis; exotic species; southern Patagonia.

Comunidad del fouling dominada por Metridium senile (Cnidaria: Anthozoa: Actiniaria) en Bahía San Julián (Patagonia austral, Argentina)

Resumen: El objetivo de este trabajo es aportar información sobre la comunidad incrustante de un puerto de la Patagonia austral dominada por Metridium senile. Varios pilotes de acero del muelle de Puerto San Julián fueron extraídos para efectuar tareas de reparación, permitiendo realizar un estudio de la comunidad bentónica adherida a ellos. El muestreo fue realizado en tres niveles: intermareal inferior, submareal a 3-4 m y submareal a 6-7 m de profundidad. En el intermareal inferior, $M$. senile presentó una abundancia relativa del 43\%, encontrándose acompañada por Perumytilus purpuratus, Mytilus edulis platensis y Aulacomya atra atra entre las especies más abundantes. En los niveles submareales presentó abundancias de 63 y $65 \%$, encontrándose acompañada por el anfípodo Monocorophium insidiosum en el nivel de 3-4 m y por poliquetos de las familias Syllidae y Sabellidae en el nivel de 6-7 m de profundidad. En el intermareal inferior, la epibiosis tuvo mayor frecuencia sobre $P$. purpuratus, A. atra atra y $M$. edulis platensis, mientras que en los niveles submareales la diversidad de organismos sustrato se incrementó significativamente, observándose fijación sobre A. atra atra, M. edulis platensis, Paramolgula gregaria, Crepipatella dilatata, Austromegabalanus psittacus, Hiatella arctica, Polyzoa opuntia, Pyura sp. y tubos de poliquetos Sabellidae. La capacidad de $M$. senile de fijarse sobre diversos organismos la convierten, junto a otras estrategias, en una eficaz colonizadora capaz de desplazar a otras especies que pueden competir con ella por el sustrato. Dada la naturaleza cosmopolita de $M$. senile, el hecho de que esta especie no ha sido registrada previamente en la zona costera de la región, y tomando en cuenta nuestros resultados, se discute la posibilidad de considerar a esta anémona como especie exótica invasora en la Patagonia austral o, al menos, como especie criptogénica.

Palabras clave: biofouling; comunidades bentónicas; Actiniaria; Metridiidae; epibiosis; especies exóticas; Patagonia austral.

Citation/Como citar este artículo: Martin J.P., Garese A., Sar A., Acuña F.H. 2015. Fouling community dominated by Metridium senile (Cnidaria: Anthozoa: Actiniaria) in Bahía San Julián (southern Patagonia, Argentina). Sci. Mar. 79(2): 211-221. doi: http://dx.doi.org/10.3989/scimar.004082.21A

Editor: J. Garrabou.

Received: April 24, 2014. Accepted: February 23, 2015. Published: March 24, 2015.

Copyright: () 2015 CSIC. This is an open-access article distributed under the Creative Commons Attribution-Non Commercial License (by-nc) Spain 3.0. 


\section{INTRODUCTION}

Studies of biofouling communities in Argentinian harbours began in the 1960s and have provided a fairly complete picture of the fouling communities from Buenos Aires Province and North Patagonia (Bastida 1971, 1973, Bastida et al. 1980, 1997, Martin et al. 2000). These studies have mainly dealt with faunal inventories, settlement cycles of species, trophic relationships, epibiosis, resistance of organisms to control biofouling substances and other general ecological topics (Bastida et al. 1976, 1980). They helped to clarify the mechanisms of colonization of these communities, as well as the processes of ecological succession on artificial substrates in marine and estuarine environments. More recently, studies were carried out in central Patagonia, specifically in the port of Comodoro Rivadavia (Rico and López Gappa 2006). However, studies of biofouling communities are virtually non-existent in southern Patagonia.

One of the objectives of studies on biofouling communities is to attempt to solve problems related to the bio-deterioration of man-made structures in the marine environment caused by organisms. These include docks, boats, facilities such as refrigeration plants and power stations that use seawater as a coolant, and underwater archaeological sites. Knowledge of the composition and succession cycle of fouling communities allows different strategies to be developed to avoid the settlement of marine organisms on artificial surfaces, or to control excessive development of communities (Bastida et al. 2004, Dürr and Thomason 2010). On the other hand, studies of fouling communities in harbours that are situated within, or adjacent to, reserve areas often have other objectives, usually related to the conservation of biodiversity. Knowledge of fouling communities settled in relatively pristine areas can establish a baseline for monitoring the impact on marine biodiversity caused by urban, port and industrial activities and detecting entry and establishment of invasive alien species related to shipping traffic (Lewis and Coutts 2010). This is the case of Bahía San Julián, which is part of a protected area within which intertidal communities have recently been studied, whereas the subtidal community is practically unknown. Knowledge of the community is particularly important in this case, as in 2013 local port activity began to recover slightly and fishing boats from harbours located northwards of the locality began to operate.

The sea anemone Metridium senile is a cosmopolitan species, predominantly found subtidally and frequently reported in biofouling communities of cold-temperate areas in the Northern Hemisphere. It often acts as a structuring species of the community by affecting the early stages of ecological succession (Nelson and Craig 2011). Riemann-Zürneck (1975) and Zamponi and Acuña (1991) reported this species in different parts of the Argentinean Continental Shelf at depths of 95-120 m. Subsequently, the species was also reported from the port of Cape Town in South Africa (Griffiths et al. 1996, Acuña and Griffiths 2004), where it was possibly introduced by shipping traffic from European ports. It is important to note that currently there is an ongoing study of different populations of $M$. senile worldwide to find out whether they are different species or subspecies (Häussermann and Försterra 2009).

In Argentina, the importance of this species in the benthic community of coastal southern Patagonia remains unknown but few studies have been done on biofouling in the region. The main goals of this study were to provide information on a fouling community dominated by $M$. senile in the harbour of Bahía San Julián, and to analyse processes of epibiosis that this anemone exerts as a strategy of colonization leading to its dominance in the community. This study also aims to provide a baseline regarding the characterization of the fouling community of Bahía San Julián, depending on the possible revival of the local fishing port and the potential risk of introduction of exotic marine species.

\section{MATERIALS AND METHODS}

\section{Study area}

Bahía San Julián is located on the central coast of Santa Cruz Province (southern Patagonia, Argentina) between $68^{\circ} 50^{\prime} 01^{\prime \prime}$ and $67^{\circ} 35^{\prime} 50^{\prime \prime} \mathrm{W}$ and $49^{\circ} 00^{\prime} 12^{\prime \prime}$ and $49^{\circ} 47^{\prime} 02^{\prime \prime}$ S (Fig. 1). It is a deep inlet of the sea about $20 \mathrm{~km}$ long and $8.8 \mathrm{~km}$ in maximum width, with a relatively narrow mouth (approximately $700 \mathrm{~m}$ wide). The Bay has a maximum depth of $35 \mathrm{~m}$ and includes a wide shallow terminal area ( $\mathrm{sac}$ ). It receives cold waters of sub-Antarctic origin and others with relatively low salinity from the Patagonian Coastal Current, a branch of the Malvinas Current. The salinity of water inside the Bay is between 33 and 34 and temperatures vary between $5^{\circ} \mathrm{C}$ (winter) and $14^{\circ} \mathrm{C}$ (summer). The tidal regime is of a semidiurnal macrotidal type, with maximum amplitude of $8.93 \mathrm{~m}$ and an average of 6.15 m (Falabella et al. 2009, SHN 2009).

The harbour of the city of Puerto San Julián, with a population of about 12000 people, is located on the northwest coast of the Bay. This has a dock comprised of a concrete manoeuvring platform $62 \mathrm{~m}$ long supported by cylindrical steel tubes. This harbour experienced increased activity in the 1990s and early 2000s, involving mainly fishing vessels but also merchant vessels. However, the port activity there was never very

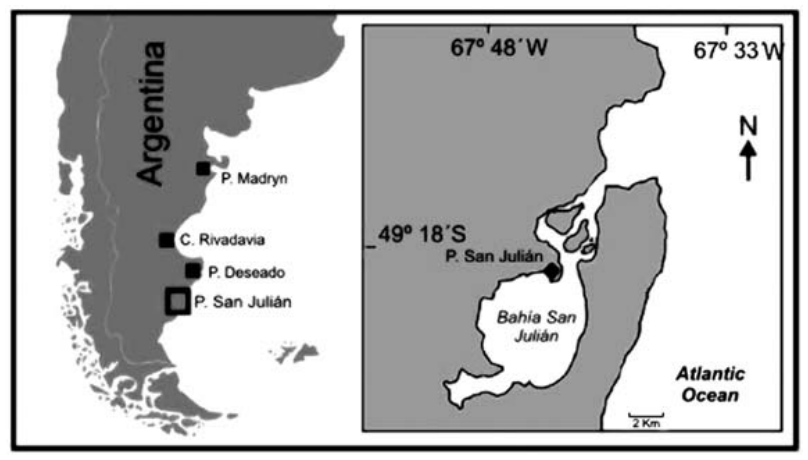

Fig. 1. - Geographic location of the study area in southern Patagonia with a detail of Bahía San Julián. 
great, being always lower than that of other harbours of the region. In 2000, for example, only four fishing vessels were registered as operating, according to the report of authorities of Puerto San Julián. Occasionally, during this period foreign flag vessels captured by authorities of the Argentina Naval Prefecture for illegal fishing operations also arrived. In 2007 repairs of the wharf commenced, with a view to the future revival of the harbour, but by 2009, when the samples of this study were taken, the port was still virtually inactive. Moreover, it is important to mention that Bahía San Julián integrates a protected area, which also includes the Cormorán and Justicia Islands that are found inside, under a protection regime of limited use. Additionally, the Peninsula of San Julián was declared as a provincial reserve (Chebez 2005).

The coast of the Bay is dominated by plains formed mainly by mud (silt + clay) and fine sand, with large extensions of intertidal mudflats on the upper levels. The mudflats are inhabited by saltmarshes of Sarcocornia perennis, and infaunal communities dominated by polychaetes and small bivalves, such as Darina solenoides and Mysella patagona in the middle and lower intertidal. Some sectors with a higher proportion of gravel enable the development of intertidal mussel beds of Perumytilus purpuratus, Mytilus edulis platensis and Aulacomya atra atra (Sar 2010, Ituarte et al. 2012). Hard substrates are scarce inside the Bay and are formed by sedimentary rocks. These areas are inhabited by intertidal communities comprised of $P$. purpuratus, M. edulis platensis and A. atra atra. These substrates are more abundant and achieve greater development in the open sea coast adjacent to the Bay, sustaining a major intertidal benthic community characterized by the development of mussel banks.

\section{Sampling and statistical analysis of the community}

In December 2009 several steel piles supporting the wharf of Puerto San Julián were extracted for repair and refurbishment. These operations allowed us to carry out the first study characterizing the fouling macrobenthos community of the lower intertidal and subtidal inside the Bay. Sampling was conducted using a framework of $20 \times 20 \mathrm{~cm}$ and metal spatula, obtaining four randomly distributed replicas from each of three different levels: Level 1, corresponding to lower intertidal; Level 2, corresponding to the subtidal between 3 and $4 \mathrm{~m}$ depth; and Level 3 , corresponding to the subtidal between 6 and $7 \mathrm{~m}$ depth (both from mean low spring tide). The samples were fixed in 5\% formalinseawater solution and transported to the laboratory for analysis. Organisms were identified to the lowest taxonomic level possible and counted under a stereoscopic microscope, then preserved in $70 \%$ alcohol. Abundance data were analysed by multivariate analysis using clustering (hierarchical agglomerative clustering) and ordination techniques (non-metric multidimensional scaling, MDS), using the Plymouth Routines in Multivariate Ecological Research (PRIMER) statistical package version 6.1 (Clarke and Warwick 2001). The data were previously transformed using square root to down-weight the effect of dominant species, and then the Bray-Curtis similarity index was applied. The statistical significance of the groups of samples was tested by analysis of similarities (ANOSIM permutation test), in order to evaluate the hypothesis of differences in community composition between depth levels. The similarity percentages (SIMPER) routine was then used to identify the main species that characterize the community at each depth level (Clarke and Warwick 2001). For each sample we calculated the number of species $S$; the diversity index of Shannon-Wiener $H^{\prime}=-\Sigma p_{i} \log \left(p_{i}\right)$, where $p_{i}$ is the proportion of the total number of individuals that belong to species $\mathrm{i}$; and Pielou evenness $\mathrm{J}=\mathrm{H}^{\prime} / \log \mathrm{S}$. The abundance data of $M$. senile and diversity of the samples were compared between sampling levels by ANOVA and post-hoc LSD test, after verifying homogeneity of variance using Levene's test (Zar 1996). The significance level used in all tests was $\mathrm{p}<0.05$.

\section{Analysis of Metridium senile epibiosis}

Settlement on other organisms and sedentary polychaete tubes, when they were inhabited, was considered epibiosis. For these studies we identified and counted all organisms that served as substrate for Metridium senile, and also the number of individuals of the sea anemone epibionts on each substrate-organisms. Epibiosis frequency $(\% \mathrm{~F})$ for each substrate-species in the sample was calculated as $\% \mathrm{~F}_{\mathrm{i}}=\mathrm{N}_{\mathrm{i}} / \mathrm{N}_{\mathrm{t}} \times 100$, where $\mathrm{N}_{\mathrm{i}}$ is the number of individuals of the $\mathrm{i}$ species upon which M. senile epibiosis was found, and $\mathrm{N}_{\mathrm{t}}$ is the total number of individuals of all species in the sample with epibiosis of $M$. senile. Furthermore, the intensity of $M$. senile epibiosis on each substrate-species was calculated as the total number of individuals of $M$. senile fixed on all individuals of the species in the sample. Spearman rank correlation analysis between the abundance of each substrate-species in the sample and the number of individuals of the substrate-species with epibiosis of $M$. senile was conducted to determine whether there was a relationship between these variables. Subsequently, we determined whether there were significant differences between the relative abundance of species-substrate in the sample and epibiosis frequency $(\% \mathrm{~F})$ using the test $\mathrm{Chi}^{2}$ for contingency tables $2 \times 2$, in order to determine if $M$. senile had higher affinity for any particular substrate-species. The average number of anemones epibionts per individual of the different substrate-species was calculated and compared by Kruskal-Wallis and Mann-Whitney tests (Zar 1996). The significance level used in all tests was $\mathrm{p}<0.05$.

\section{RESULTS}

\section{Community composition and abundance of Metridium senile}

The fouling community was dominated by Metridium senile in all the three studied levels. This species was found together with different groups of macrozoobenthos organisms, varying in importance in the 


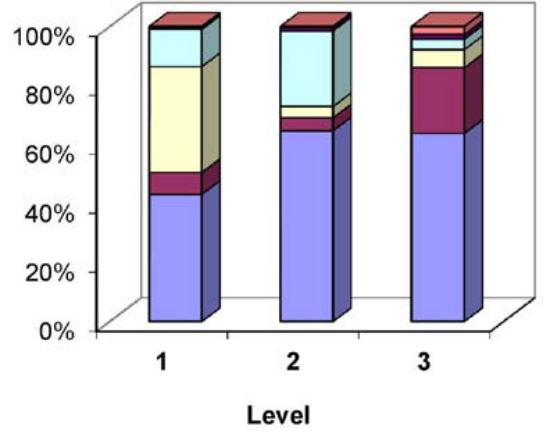

口Other

-Tunicates

口Crustaceans

口Molluscs

口Polychaetes

$\square$ Metridium senile

Fig 2. - Relative abundance of $M$. senile and principal groups of macrozoobenthos at the diferents levels: 1, intertidal; 2, subtidal (3-4 m); 3, subtidal (6-7 m). community according to sampling depth (Figs 2 and 3 ). Table 1 lists all taxa identified in the community, with their respective observed average abundances per level.

The abundance of $M$. senile was high in the three levels studied and peaked at Level 2, which showed significant differences from the other two levels (Fig. 4) (ANOVA $\mathrm{F}_{2,9}=5.687, \mathrm{p}=0.025$, LSD Test $2>1$, $\mathrm{p}=0.0125,2>3, \mathrm{p}=0.0247)$.

At Level 1 (lower intertidal), M. senile had an average relative abundance of $43 \%$, and was accompanied by the mussels Perumytilus purpuratus (17.5\%) and Aulacomya atra atra (12.9\%) among the most abundant species. Density of $M$. senile at this level reached 12900 ind. $\mathrm{m}^{-2}$ with an average of 10406 ind. $\mathrm{m}^{-2}$.
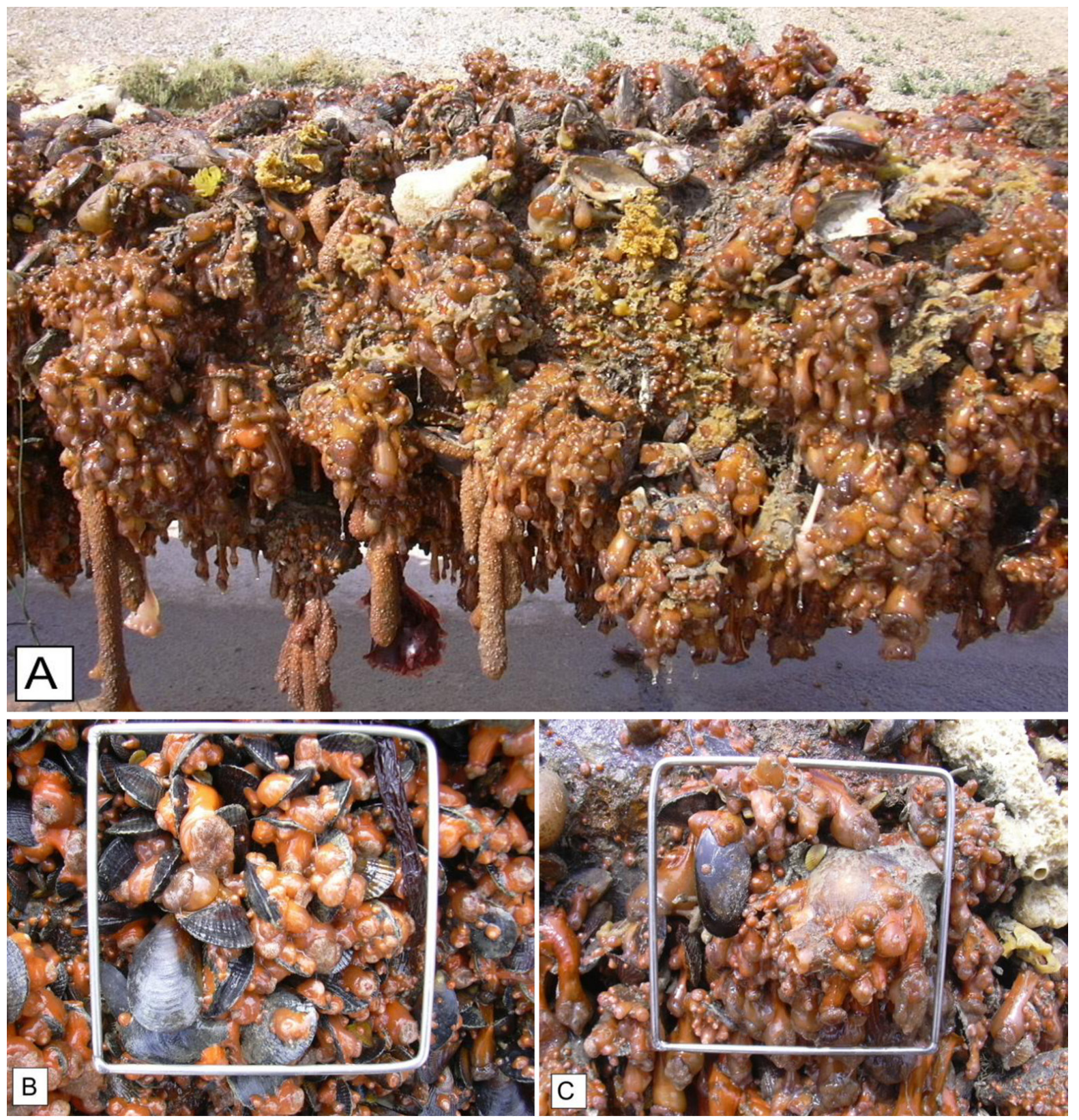

Fig. 3. - A, Biofouling community dominated by Metridium senile settled on steel piles supporting the wharf of Puerto San Julián. B, M. senile settled on the mussels Mytilus edulis platensis and Aulacomya atra atra at Level 1. C, M. senile settled on mussels and the sea squirt Paramolgula gregaria at Level 2. 
Table 1. - List of taxa found in the fouling community of Bahía San Julián and their average abundances for depth level. In cases of Porifera and bryozoans their abundance are indicated with "+" signs, each "+" indicating its presence in one replica (from one to four).

\begin{tabular}{|c|c|c|c|c|}
\hline & & Level 1 & Level 2 & Level 3 \\
\hline Porifera & Porifera indet. & + & ++ & ++++ \\
\hline \multirow[t]{2}{*}{ Cnidaria } & Metridium senile & 416.25 & 1001.75 & 494.75 \\
\hline & Hydrozoos indet. & 0.75 & 0 & 0 \\
\hline Nematoda & Nematodes indet. & 0 & 1.75 & 13.25 \\
\hline Nemertea & Nemerteans indet. & 3.25 & 3.25 & 5 \\
\hline \multirow[t]{15}{*}{ Polychaeta } & Cirratulus sp. & 11.75 & 0.75 & 18.25 \\
\hline & Cirriformia filigera & 5 & 0 & 8.25 \\
\hline & Cirratulidae indet. & 5 & 2 & 10 \\
\hline & Syllis sp. & 25 & 16.5 & 45 \\
\hline & Syllidae indet. & 0.75 & 5.75 & 3.25 \\
\hline & Bispira magalhaensis & 3.25 & 10.5 & 38.25 \\
\hline & Potamilla antarctica & 0 & 0.25 & 22.5 \\
\hline & Thelepus plagiostoma & 6.75 & 17.25 & 0 \\
\hline & Hallosydna patagonica & 0 & 0.5 & 4.75 \\
\hline & Eunoe opalina & 1 & 3 & 9.25 \\
\hline & Spionidae indet. & 9.5 & 7.5 & 1.75 \\
\hline & Eteoninae & 1 & 2 & 4.5 \\
\hline & Arabella sp. & 0.5 & 1.25 & 5.25 \\
\hline & Aricidea sp. & 0 & 0 & 0.25 \\
\hline & Pherusa cf. laevis & 0.75 & 0.25 & 1 \\
\hline Bryozoa & Bryozoans indet. & + & 0 & ++ \\
\hline Brachiopoda & Magellania venosa & 0 & 0 & 0.75 \\
\hline \multirow[t]{12}{*}{ Mollusca } & Perumytilus purpuratus & 168.75 & 5.5 & 0 \\
\hline & Mytilus edulis platensis & 31 & 2.75 & 0.75 \\
\hline & Aulacomya atra atra & 124.5 & 32.5 & 1.5 \\
\hline & Lasaea consanguinea & 0.25 & 0 & 0 \\
\hline & Hiatella arctica & 19.5 & 16.25 & 16.5 \\
\hline & Siphonaria lessoni & 1.25 & 0 & 0 \\
\hline & Crepipatella dilatata & 0 & 0 & 25.25 \\
\hline & Fissurella sp. & 0 & 0 & 1.25 \\
\hline & Trophon geversianus & 0.75 & 0.5 & 0 \\
\hline & Pareuthria plumbea & 0 & 1.25 & 2.5 \\
\hline & Photinula taeniata & 0 & 0.25 & 0 \\
\hline & Xymenopsis sp. & 0,5 & 0.25 & 0 \\
\hline \multirow[t]{8}{*}{ Crustacea } & Austromegabalanus psittacus & 53.75 & 1.75 & 0 \\
\hline & Elminius kingii & 15.25 & 2 & 0 \\
\hline & Balanus laevis & 3.25 & 0 & 0 \\
\hline & Monocorophium insidiosum & 27 & 290 & 12.5 \\
\hline & Exosphaeroma calcareum & 11.5 & 8.75 & 6.25 \\
\hline & Joeropsis sp. & 0 & 4.25 & 7.25 \\
\hline & Halicarcinus planatus & 1.75 & 0.25 & 0.25 \\
\hline & Peltarion espinosulum & 0.25 & 0 & 0 \\
\hline Pycnogonida & Pycnogonids indet. & 0 & 0 & 0.25 \\
\hline Equinodermata & Amphiura sp. & 0 & 0.25 & 1.5 \\
\hline \multirow[t]{5}{*}{ Tunicata } & Paramolgula gregaria & 5 & 4.5 & 4.5 \\
\hline & Pyura sp. & 0 & 3.25 & 0 \\
\hline & Polizoa opuntia & 0 & 7.5 & 4.5 \\
\hline & Amaroucium sp. & 0 & 1.5 & 1.5 \\
\hline & Colonial tunicates indet. & 0 & 1.5 & 1.5 \\
\hline
\end{tabular}

At Level 2 (3-4 m depth), M. senile had an average relative abundance of $64.6 \%$ followed by the amphipod Monocorophium insidiosum (18.7\%). The maximum density of $M$. senile was 38200 ind. $\mathrm{m}^{-2}$ with an average of 25044 ind. $\mathrm{m}^{-2}$.

At Level 3 (6-7 m depth) M. senile relative abundance reached an average of $63.7 \%$, being accompanied by polychaetes of the family Syllidae $(5.8 \%)$ and the Sabellidae Bispira magalhaensis (5\%). The maximum density of $M$. senile was 20075 ind. $\mathrm{m}^{-2}$ with an average of 12369 ind. $\mathrm{m}^{-2}$.

The diversity of the community peaked at Level 1 , significant differences were observed with respect to Level 2 (ANOVA $F_{2,9}=5.06, \mathrm{p}=0.03$, LSD Test $1>2$, $\mathrm{p}=0.0124$ ), and the lowest value was recorded at Level 2 , coinciding with the lowest number of species in the community and the greater abundance of $M$. senile and M. insidiosum, which together accounted for over $83 \%$ of total faunal abundance (Fig. 5).

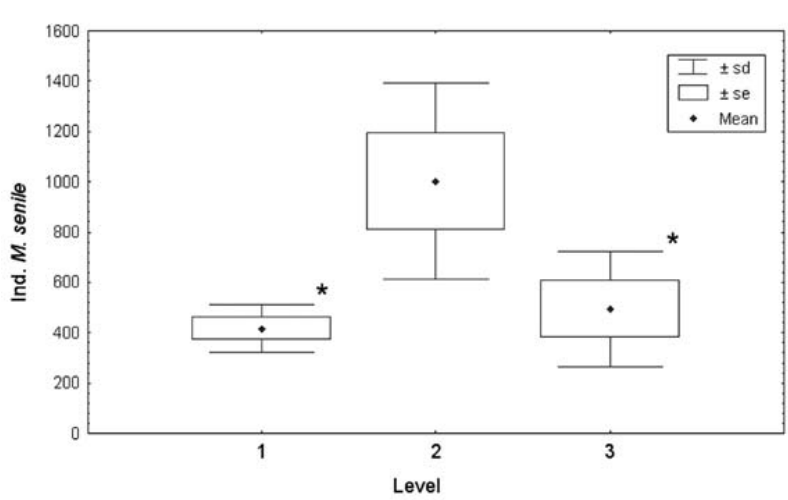

Fig. 4. - Abundance of M. senile at the different levels: 1, intertidal; 2, subtidal (3-4 m); 3, subtidal (6-7 m). * Levels that showed no significant differences.

The two-dimensional MDS plot showed a clear separation of samples by depth level (Fig. 6). The 

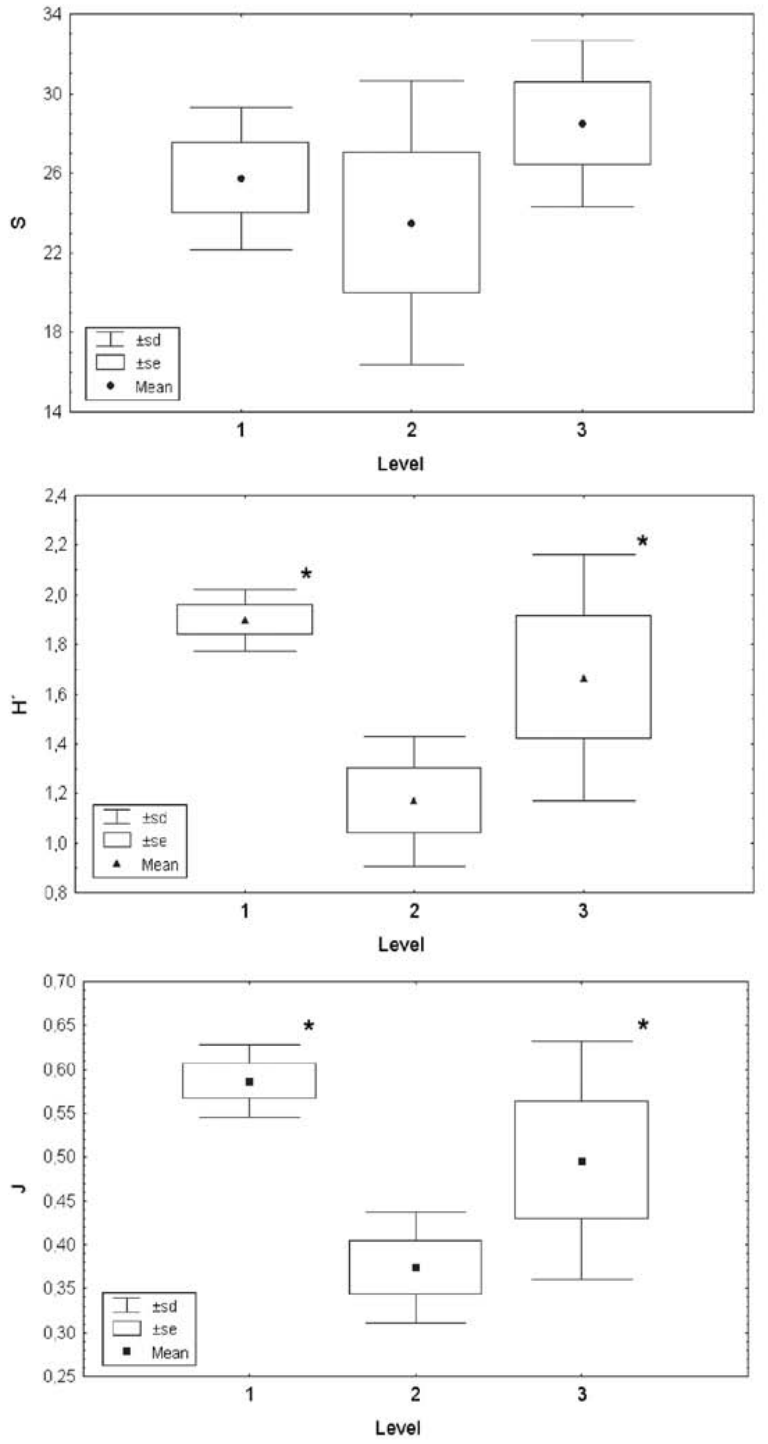

Fig. 5. - Number of species (S), diversity $\left(\mathrm{H}^{\prime}\right)$ and evenness (J) of fouling community in the three levels: 1 , intertidal; 2 , subtidal (3-4 m); 3, subtidal $(6-7 \mathrm{~m})$. * Levels that showed no significant differences.

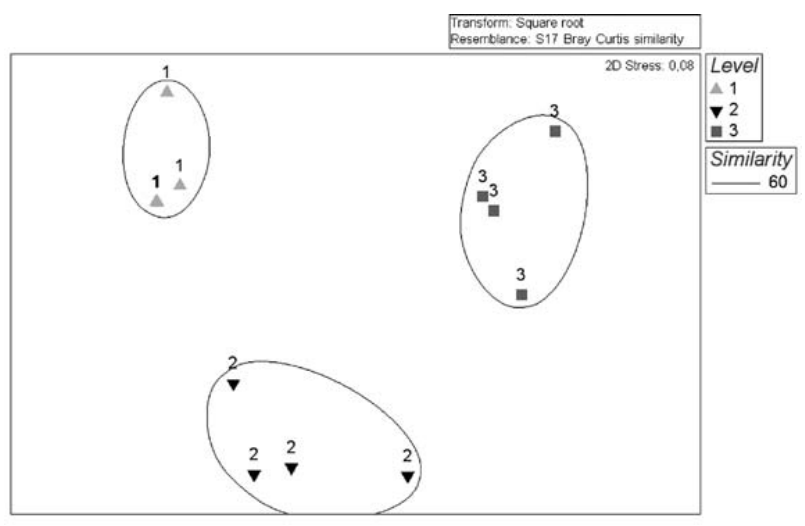

Fig. 6. - Bi-dimensional MDS plot of samples from different depth levels based on abundance of species. Continuous line encloses the group-averaged clustering identified with a hierarchical agglomerative clustering technique.

ANOSIM test between groups of samples indicated that community structure differs significantly between levels of depth in species composition (Global $\mathrm{R}=0.984, \mathrm{p}=0.001 ; \mathrm{R}_{1,2}=0.958, \mathrm{p}=0.03 ; \mathrm{R}_{1,3}=1, \mathrm{p}=0.03$; $\mathrm{R}_{2,3}=0.979, \mathrm{p}=0.03$ ). The SIMPER routine allowed us to identify the species which contributed most to the similarity between samples in each group (Table 2), and therefore those species that characterized the community at each level studied. M. senile and Syllidae polychaetes were characteristic of the community at all levels, while other companion species varied markedly between levels. P. purpuratus, A. atra atra, M. edulis platensis and Austromegabalanus psittacus were the most characteristics species at Level 1, Monocorophium insidiosum was the companion species that characterized the community at Level 2, and Bispira magalhaensis, Cirratulus sp., Potamilla antarctica, Hiatella arctica and M. insidiosum were characteristic of Level 3.

\section{Metridium senile epibiosis}

Metridium senile settled directly to the surface of the piles and upon different sessile or low-mobility organisms present in the community, as well as on structures of biological origin, such as sedentary poly-

Table 2. - Contribution of species to the similitude between samples from the same level (SIMPER routine).

\begin{tabular}{|c|c|c|c|}
\hline & Mean Abundance & $\%$ Contribution & $\%$ Cumulative \\
\hline \multicolumn{4}{|l|}{ Level 1: Average similitude $=79.38$} \\
\hline Metridium senile & 416.25 & 22.05 & 22.05 \\
\hline Perumytilus purpurates & 168.75 & 12.8 & 34.85 \\
\hline Aulacomya atra atra & 124.5 & 12.32 & 47.17 \\
\hline Syllidae & 25.75 & 5.5 & 52.68 \\
\hline Mytilus edulis platensis & 31 & 5.48 & 58.15 \\
\hline Austromegabalanus psittacus & 53.75 & 5.32 & 63.47 \\
\hline \multicolumn{4}{|l|}{ Level 2: Average similitude $=66.19$} \\
\hline Metridium senile & 1001.75 & 39.3 & 39.3 \\
\hline Monocorophium insidiosum & 290 & 17.87 & 57.17 \\
\hline Syllidae & 21.80 & 5.28 & 62.46 \\
\hline \multicolumn{4}{|l|}{ Level 3: Average similitude $=73.07$} \\
\hline Metridium senile & 494.75 & 26.75 & 26.75 \\
\hline Syllidae & 48.25 & 8.17 & 34.92 \\
\hline Bispira magalhaensis & 38.25 & 7.37 & 42.29 \\
\hline Cirratulus sp. & 18.25 & 5.24 & 47.53 \\
\hline Potamilla antarctica & 22.5 & 4.7 & 52.23 \\
\hline Hiatella arctica & 16.5 & 4.59 & 56.82 \\
\hline Monocorophium insidiosum & 12.5 & 4.43 & 61.25 \\
\hline
\end{tabular}




\section{Level 1}

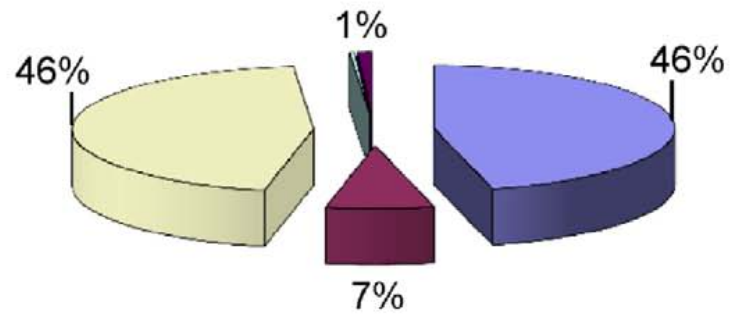

\section{Level 2}

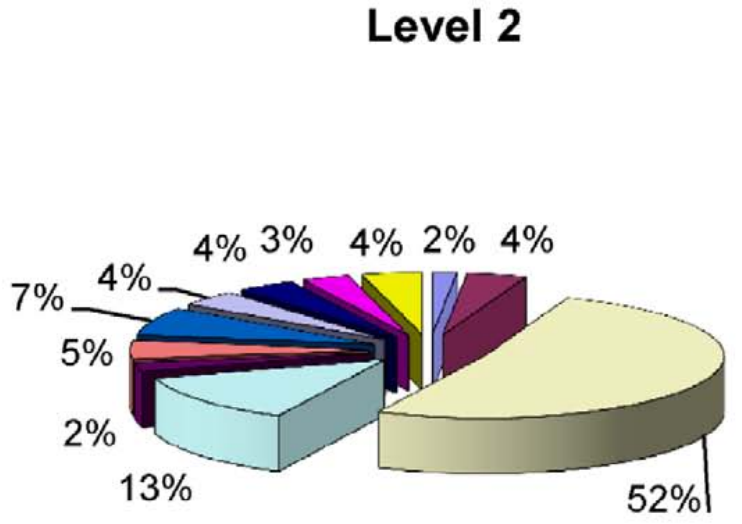

Level 3

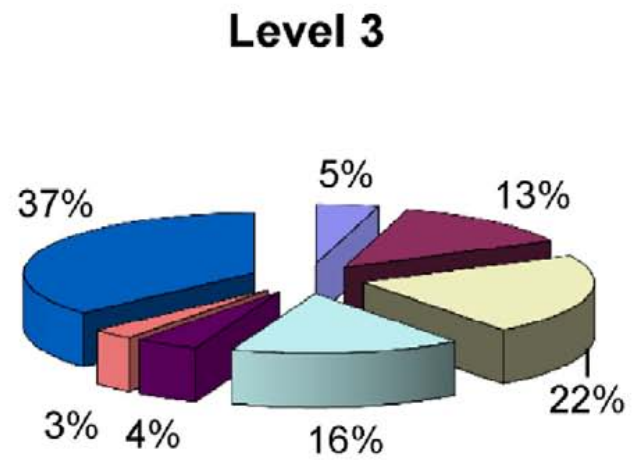

$\square$ Perumytilus purpuratus

口Mytilus edulis platensis

口Aulacomya atra atra

口Paramolgula gregaria

- Austromegabalanus psittacus

\author{
口Perumytilus purpuratus \\ 口Mytilus edulis platensis \\ 口Aulacomya atra atra \\ 口Paramolgula gregaria \\ - Austromegabalanus psittacus \\ 口Hiatella arctica \\ -Bispira magalhaensis \\ 口Pyura sp. \\ - Polyzoa opuntia \\ 口Col. Tunicates indet. \\ 口Thelepus plagiostoma
}

\section{-Aulacomya atra atra}

-Paramolgula gregaria

口Bispira magalhaensis

\section{口Potamilla antarctica}

-Polyzoa opuntia

口Col. Tunicates indet.

- Crepipatella dilatata

Fig. 7. - Mean epibiosis frecuency (F\%) on each substrate-organism used by M. senile.

chaete tubes. In Level 1, M. senile was epibiont on five different species. The substrates with the highest frequency of epibiosis $(\% \mathrm{~F})$ at this level were the mussels Perumytilus purpuratus and Aulacomya atra atra, which accounted for $98 \%$ of the biological substrates utilized by the sea anemone (Figs 3 and 7).

In subtidal levels, the richness of biological substrates increased significantly. At Level 2, the number of biological substrates used was 12 , the highest frequency of epibiosis being upon A. atra atra (52\%) and Paramolgula gregaria (13\%) (Figs 3 and 7).

At Level 3, epibiosis on seven organisms was observed, with the greatest frequency on Crepipatella dilatata $(37 \%)$, Sabellidae polychaete tubes $(38 \%$ overall) and $P$. gregaria (13\%), see Figure 7.

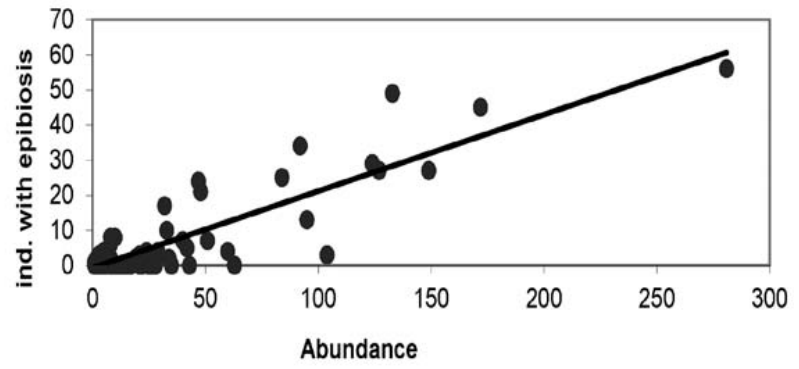

Fig. 8. - Correlation betweeen the number of individuals of each species with epibiosis of $M$. senile and the abundance (total number of individuals in the sample) of each substrate-species (each point represent a substrate-species in a sample). 


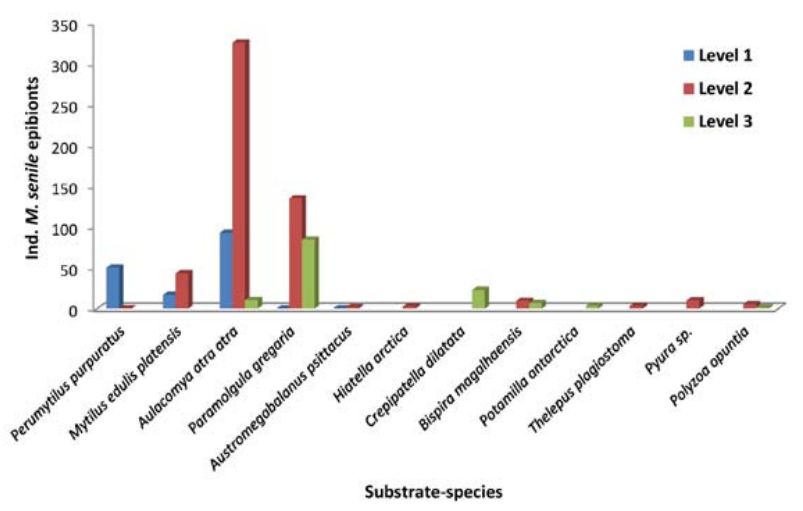

Fig. 9. - Mean epibiosis intensity of $M$. senile shown as number of epibionts on all individuals of each substrate-species in the sample.

The abundance of different substrate-species in the samples showed a significant correlation with the number of individuals of each species with epibiosis by $M$. senile $\left(\mathrm{r}_{\mathrm{s}}=0.51, \mathrm{t}_{(87)}=5.51, \mathrm{p}<0.0001\right)$ (Fig. 8). Moreover, no significant differences between the relative abundance of substrate-species in the samples and epibiosis frequency $(\% \mathrm{~F})$ indicated that, in general, $M$. senile showed no preference for any particular substrate. Significant differences were found only for Austromegabalanus psittacus at Level $1\left(\chi^{2}=7.39, \mathrm{p}=0.006\right)$. In this case, the barnacle comprised an average relative abundance of $14 \%$ among the substrate-species of $M$. senile, but had an epibiosis frequency lower than $1 \%$, indicating that there was a negative selection of $M$. senile for this substrate at this depth level.

Epibiosis intensity of M. senile (Fig. 9) at Level 1 was higher on the mussels $P$. purpuratus and $A$. atra atra. In the latter species up to 138 sea anemones were recorded on the total specimens in a sample. At Level 2 , the highest intensity of epibiosis was observed on $A$. atra atra, $P$. gregaria and $M$. edulis platensis. At this level the intensity of epibiosis on A. atra atra reached 570 individuals of M. senile. At Level 3, epibiosis intensity was higher on $P$. gregaria, with a maximum of 198 individuals of the sea anemone recorded.

The average number of anemones epibionts per individual of substrate-species (Fig. 10) at Level 1 was highest on the mussels $A$. atra atra ( 0.81 epibionts per individual) and $M$. edulis platensis ( 0.5 epibionts per individual). At Level 2, the highest number of epibionts per individual was observed on $P$. gregaria, $A$. atra atra and $M$. edulis platensis, with averages of 25.5, 15.5 and 14.5 respectively. At Level 3, the number of epibionts per individual was higher on $P$. gregaria, with an average of 18 anemones recorded per host.

\section{DISCUSSION}

The fouling community from Bahía San Julián showed similar traits in its composition to those found in natural rocky substrates in the region, with a high abundance of mussels in lower intertidal levels, from where they were progressively replaced by other species in the subtidal. In the Ría Deseado $(200 \mathrm{~km} \mathrm{~N}$ of Bahía San Julián), the association of Perumytilus
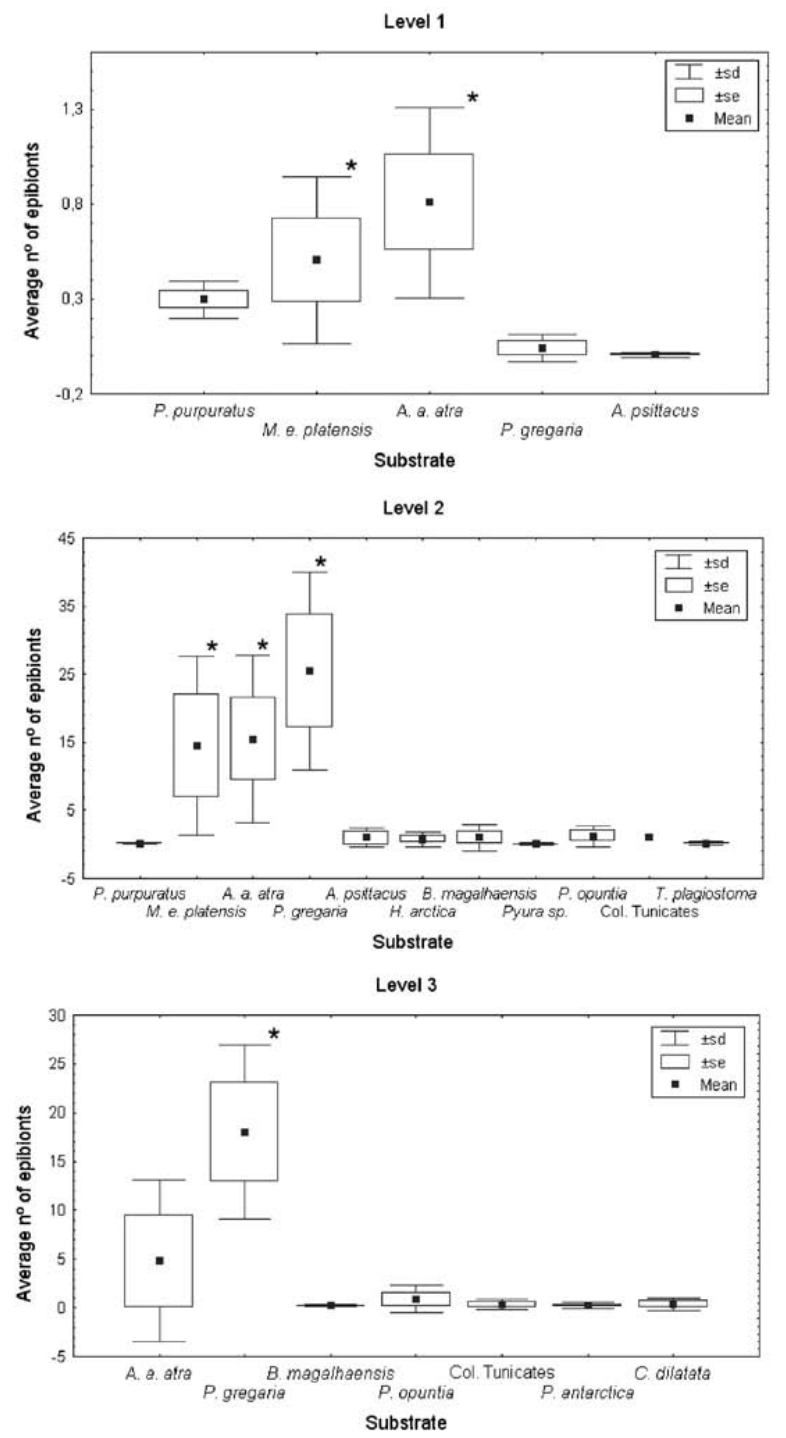

Fig. 10. - Average number of anemone epibionts per individual of the different substrate species. $*$ Substrates that showed significant differences $(\mathrm{p}<0.05)$.

purpuratus, Mytilus edulis platensis and Aulacomya atra atra dominates and characterizes the community in the lower intertidal level, mainly in the vertical rocky substrates inside the ría. In the shallow subtidal, the community of Ría Deseado is characterized by a decrease in the abundances of $P$. purpuratus and $M$. edulis platensis and a predominance of A. atra atra and Polyzoa opuntia, accompanied by Paramolgula gregaria, Crepidula dilatata dilatata (=Crepipatella dilatata), Photinula caerulescens, Balanus psittacus (=Austromegabalanus psittacus), Aerothyris venosa (=Magellania venosa) among the most conspicuous species (Ringuelet et al. 1962, Otaegui and Zaixso 1974, Zaixso and Pastor 1977). Despite the similarities found in the community of vertical hard substrates between the two sites, the absence of the sea anemone $M$. senile in works of the 1960s, 1970s and early 1980s in the Ría Deseado is striking. Indeed the very low abundance of Actiniaria as a group in the subtidal of Ría Deseado (Callebaut Cardu and Borzone 1979) is very 
different from the situation found in the present study, in which Actiniaria, represented only by $M$. senile, was a dominant group. Moreover, López Gappa et al. (1982) recorded the following actiniarians among fauna associated with Macrocystis pyrifera holdfast in Ría Deseado: Isoedwardsia nidarosiensis, Aiptasiamorpha minima, Acontiophorum mortenseni and Isanthus capensis. All of these showed very low abundance in the community.

The only exotic species of the fouling community of Bahía San Julián identified was the gammarid amphipod Monocorophium insidiosum, which is characterized as invasive on the coast of Argentina. This species, usually seen in high densities in biofouling of harbours, is widely distributed in the world, being transported mainly by human action. In Argentina, it was detected in the harbour-fouling community of Mar del Plata in the 1970s, when it was identified as Corophium comparable with Corophium insidiosum. Subsequently, it was reported for other harbours of Buenos Aires Province and the Patagonian coast (Bastida et al. 1980, Alonso de Pina 1997, Martin et al. 2000, Orensanz et al. 2002).

The virtual absence of exotic species in fouling and natural hard substrate communities of Bahía San Julián is in marked contrast with fouling from other harbours of the region, such as Puerto Madryn, Puerto Deseado and Comodoro Rivadavia (Fig. 1), which have high shipping activity. In these harbours several invasive alien species have been reported in recent years, such as Undaria pinnatifida, Carcinus maenas, Ascidiella aspersa, Balanus glandula and Cryptosula pallasiana (Piriz and Casas 1994, Orensanz et al. 2002, Hidalgo et al. 2005, Cuevas et al. 2006, Rico and López Gappa 2006, Martin and Cuevas 2006, Schwindt 2007, Martin and Bastida 2008). However, none has been found so far in Bahía San Julián. The low shipping activity in the local harbour, which has been practically inactive for several years, could be responsible for the absence of exotic species common in other harbours of the region. The absence of these alien species is consistent with the assumption that the dispersion along the Patagonian coast is fundamentally linked to commercial shipping traffic (commercial fishing and transport) and the passive spread by currents has limited scattering power due to the large extension of the coast. Thus, this study provides interesting information on this problem and provided a baseline for Bahía San Julián, especially taking into account the possible reactivation of port activities in the locality.

A particular feature of the fouling community of Bahía San Julián is the dominance of the sea anemone Metridium senile at all levels sampled. This funding has not been reported so far in the intertidal or subtidal natural hard substrates from the region. However, $M$. senile is currently a common species in hard substrate communities from the open sea around Bahía San Julián, along with other species of sea anemones, such as Antholoba achates and Bunodactis octoradiata (Garese et al. 2014). This sea anemone forms aggregates in free lower intertidal substrates, usually in tidal pools and on horizontal and vertical walls, and to a lesser extent as an epibiont (Acuña et al. 2011). This suggests that protected conditions in the inner of Bahía San Julián and the existence of a limited, but stable artificial substrate generate a suitable environment for successfully settlement of a sea anemone population, reaching high abundances and dominating the community. A similar phenomenon was observed in harbour biofouling of cold-temperate areas in the Northern Hemisphere (Nelson and Craig 2011).

It is important to note that $M$. senile is also currently an abundant species within the Ría Deseado, where it mainly inhabits the lower intertidal and shallow subtidal rocky substrate (Acuña et al. 2011). In that location, it can also be observed in intertidal shores composed of fragments of rock and mud inside the port and surrounding areas, and as an epibiont of the seaweeds $U n$ daria pinnatifida, Macrocystis pyrifera and Lessonia sp. (Martin unpublished data). However, as mentioned above, the species was not cited in previous works in that locality in the 1960s 1970 s and early 1980 s (Ringuelet et al. 1962, Zaixso 1975, Zaixso and Pastor 1977, Callebaut Cardu and Borzone 1979, López Gappa et al. 1982), which suggests that its entry to the Ría Deseado could have occurred from the mid-1980s or 1990s, when commercial shipping traffic and fishing activity started and intensified in that locality. It is also important to note that the existence of this species could not be confirmed along the Chilean coast, despite extensive samplings conducted in the last decade (Häussermann and Försterra 2005, Häussermann 2006).

At San Julián harbour, shipping activity reached its peak during the 1990s, when fishing vessels operated from Argentinian harbours located northwards (e.g. P. Madryn and C. Rivadavia), and from some from foreign harbours. During the 1990s, for example, vessels from Spain and Cape Town (South Africa), where $M$. senile has been recorded as an invasive alien species since 1995 (Griffiths et al. 1996), were recorded as entering Bahía San Julián. Given the cosmopolitan nature of $M$. senile, its high abundance at present, and the fact that it has not been cited in previous works on the region, we recommend granting this anemone the status of an alien invasive species in Argentina, or at least the rank of a cryptogenic species: one for which it is not possible to demonstrate whether it is native or introduced (Carlton 1996).

There are several factors that make $M$. senile the dominant species of the biofouling community of San Julián harbour, one of which is its great ability to bind to different substrates, including other sessile organisms or structures derived from them, as in the case of polychaete tubes. The analysis of epibiosis processes shows that the biological substrates commonly used by M. senile are molluscs, in particular the mussel A. atra atra, the gastropod Crepipatella dilatata, and the tunicate Paramolgula gregaria. However, this would not be a result of active selection of these biological substrates. The significant correlation observed between the abundance of substrate-species and the number of individuals of such species with epibiosis indicates that the frequency with which a given organism is used as a substrate for $M$. senile is determined largely by its 
abundance. Furthermore, statistical analysis makes it clear that there is no difference between the relative abundance of substrate-species and their frequency of use $(\% \mathrm{~F})$, indicating that there is no selection of them by the anemone. Neither do the substrate-species exhibit effective mechanisms to prevent or inhibit the binding of the anemone, although, for example, cleaning behaviour to avoid epibiosis was described for Mytilus edulis by Theisen (1972) and Bruzzone (1982). Moreover, analysis of the attachment intensity and average number of epibionts per individual suggests that the number of anemones settled on a substrate species is also linked to the size of the substrate and the surface available for epibiosis. Thus, although the sea squirt $P$. gregaria is not an abundant species in the community, it is one of the most intensively used substrates in the subtidal levels, due to the large size of its specimens and hence the large surface available for settlement of the sea anemones. A. psittacus, was found to have a negative selection as a substrate at Level 1 because, despite its relatively high abundance in the community, the epibiosis frequency was very low on this organism, possibly because they were of very small size at this level $($ mean $=13.64 \mathrm{~mm}$, $\mathrm{sd}=5.76 \mathrm{~mm}$ basal diameter), providing a very small attachment surface. This was not the case at Level 2 where, though the abundance of barnacle is much lower than that at Level 1, the specimens were significantly larger $($ mean $=43.48$ $\mathrm{mm}$, sd $=3.68 \mathrm{~mm}$ basal diameter), offering a wider attachment surface for $M$. senile. In the latter case, no differences between the relative abundance of the barnacle in the community and the epibiosis frequency on the barnacle were observed.

We conclude that for $M$. senile the frequency and intensity of epibiosis is primarily determined by abundance and size of each substrate-species available. This underlines the high plasticity of the anemone to attach on several substrates, increasing their characteristic capacity of colonization. Thus, epibiosis emerges as a strategy of colonization when hard substrate availability is scarce, as is common for many benthic organisms (Wahl 1997), and it is particularly important for $M$. senile inside Bahía San Julián.

The high ability for epibiosis reinforces the potential of colonization of $M$. senile and, with other biological characteristics, allows us to understand its great adaptation to harbour environments and its cosmopolitan distribution. These features include the clonal mode of reproduction, sustained mainly by pedal laceration. This mode of asexual reproduction is typical of subtidal anemones and, according to the hypothesis of Sibly and Calow (1982), would be selected to promote growth in favourable environments such as the subtidal, while longitudinal fission would be the dominant mode in less favourable environments for growth, such as the intertidal zone. In the Northern Hemisphere (Gulf of Maine, USA), similar results for the same sea anemone were observed, where it was dominant in a community of subtidal rocky substrate and prevailed upon ascidians, bryozoans, sponges, coralline algae and other anthozoans (Sebens 1986). The aforementioned author highlights the rapid growth of the anemone and its dense aggregation, which excludes even colonial ascidians, as mechanisms that determine the competitive success of this species. It should also be noted that this anemone can develop tentacles with aggressive feature (catch tentacles), that may prevent or limit the settlement of other organisms, especially genetically different clones of the same species. In dense populations of $M$. senile, where essentially all space is occupied, the catch tentacles are lost because of "habituation" or "induced tolerance" to neighbours (Shick 1991).

In some subtidal communities in the Northern Hemisphere, mussels provide an important secondary substrate for populations of $M$. senile, showing coverage of up to $100 \%$ (i.e. Kaplan 1984). However, the mobility of mussel patch aggregates can frequently result in the death of their epibionts, which can be buried or located in unfavourable positions incompatible with life. Thus, the relative instability of the biological substrate, such as mussels, stimulates locomotion of the anemone causing the laceration of the pedal disc and the clonal reproduction of individuals, as observed by Kenneth et al. (1995). Moreover, experiments carried out by Nelson and Craig (2011) on artificial substrates show that the movements of $M$. senile kill new recruits from other fouling organisms by asphyxiation (smothering), possibly due to stress conditions generated by the low concentration of dissolved oxygen below the pedal disc. This process would allow M. senile to eliminate potential space competitors of surrounding substrate and continue dominating the space inside the fouling community. The dominance of $M$. senile observed in the fouling community of Bahía San Julián may then be explained by the effect on new recruits demonstrated by Nelson and Craig (2011) and also by its ability to settle on a wide range of biological substrates.

\section{ACKNOWLEDGEMENTS}

The authors wish to thank Technician Carlos Caminos (UNPA) for his assistance in the separation and quantification of organisms. This work was partially funded by PIP 0011 (CONICET) and EXA 648/14 granted to FHA. Special thanks to Ricardo Bastida and the anonymous reviewers for their constructive comments and suggestions. Also, we are grateful to Charles Griffiths (University of Cape Town), who greatly improved the English version of the manuscript.

\section{REFERENCES}

Acuña F.H., Griffiths C.L. 2004. Species richness, endemicity and distribution patterns of South African sea anemones (Cnidaria: Actiniaria \& Corallimorpharia). Afr. Zool. 39: 193-200.

Acuña F.H., Martin J.P., Garese A., et al. 2011. Diversidad, biología y ecología de anémonas de mar (Cnidaria, Anthozoa) de las costas de Santa Cruz (Patagonia austral, Argentina). Extended abstract, COLACMAR, 4 pp.

Alonso de Pina G.M. 1997. Records of intertidal amphipods from the southwest Atlantic, with the description of a new species of Elasmopus. J. Crustac. Biol. 17: 745-757. http://dx.doi.org/10.2307/1549377

Bastida R. 1971. Las incrustaciones biológicas en el puerto de Mar del Plata, Período 1966/1967. Rev. Mus. Argent. Cienc. Nat. 
"Bernardino Rivadavia" 3: 203-285.

Bastida R. 1973. Studies of the fouling communities along Argentine coasts. Proceedings 3rd. International Congress on Marine Corrosion and Fouling, pp. 847-864.

Bastida R., Adabbo H., Rascio V. 1976. Toxic action of antifouling paints with different toxicant concentrations. Corros. Mar. Foul. 1/76: 5-17.

Bastida R., Trivi M., Lichtschein V., et al. 1980. Ecological aspects of marine fouling at the Port of Mar del Plata (Argentina). V Congreso Internacional de Corrosión Marina e Incrustaciones. Sección Biología Marina, pp. 299-320.

Bastida R., Martin J.P., Ieno E. 1997. Comunidades incrustantes de áreas costeras naturales del sur de la Provincia de Buenos Aires (Argentina). CIDEPINT, Anales 1997-98: 171-198.

Bastida R., Elkin D., Grosso M., et al. 2004. The sloop of war HMS Swift (1770): a case study on the effects of biodeterioration on the underwater cultural heritage of Patagonia. Corr. Rev. 22: 417-440. http://dx.doi.org/10.1515/CORRREV.2004.22.5-6.417

Bruzzone J.H. 1982. Funciones del pie en Mytilus edulis chilensis (Hupe). Physis, Sección A 41: 51-61.

Callebaut Cardu J., Borzone C.A. 1979. Observaciones ecológicas del infralitoral de Puerto Deseado (Provincia de Santa Cruz, Argentina). I. Península Foca. ECOSUR 6: 45-54.

Carlton J.T. 1996. Biological invasions and cryptogenic species. Ecology 77: 1653-1655. http://dx.doi.org/10.2307/2265767

Chebez J.C. 2005. Guía de las reservas naturales de la Argentina. Patagonia austral. Ed. Albatros, Buenos Aires, 192 pp.

Clarke K.R., Warwick R.M. 2001. Change in marine communities: an approach to statistical analysis and interpretation. PRIMERE, Plymouth, $159 \mathrm{pp}$

Cuevas J.M., Martin J.P., Bastida R. 2006. Benthic community changes in a Patagonian intertidal: a forty years later comparison. Thalassas 22: 31-39.

Dürr S., Thomason J. (eds) 2010. Biofouling. Wiley and Blackwell, Oxford, $410 \mathrm{pp}$.

Falabella V., Campagna C., Croxall J. (eds). 2009. Atlas del Mar Patagónico. Especies y Espacios. Buenos Aires, Wildlife Conservation Society y BirdLife International. http://www.atlasmarpatagonico.org.

Garese A., Longo M. V., Martin J.P., et al. 2014. The sea anemone Bunodactis octoradiata (Anthozoa: Actiniaria) from southern Patagonia: morphological study and new records). Zoologia 31: 475-481. http://dx.doi.org/10.1590/S1984-46702014000500007

Griffiths C.L., Kruger L.M., Ewart Smith C. 1996. First record of the sea anemone Metridium senile from South Africa. S. Afr. J. Zool. 31: 157-158.

Häussermann V. 2006. Biodiversity of Chilean sea anemones (Cnidaria: Anthozoa): distribution patterns and zoogeographic implications, including new records for the fjord region. Invest. Mar., 34: 23-35.

Häussermann V., Försterra G. 2005. Distribution patterns of Chilean shallow-water sea anemones (Cnidaria: Anthozoa: Actiniaria, Corallimorpharia); with a discussion of the taxonomic and zoogeographic relationships between the actinofauna of the South East Pacific, the South West Atlantic and the Antarctic. Sci. Mar. 69: 91-102.

Häussermann V., Försterra G. 2009. Actiniaria - Anémonas de Mar. In: Häussermann V., Försterra G. (eds), Fauna marina bentónica de la Patagonia Chilena. Santiago Nature in Focus, pp. 215-266.

Hidalgo F.J., Barón P.J., Orensanz J.M. 2005. A prediction come true: the green crab invades the Patagonian coast. Biol. Inv. 7: 547-552.

http://dx.doi.org/10.1007/s10530-004-5452-3

Ituarte C, Martin J.P., Zelaya D.G. 2012. A new species of Mysella from Patagonia (Bivalvia: Galeommatoidea). Nautilus 126: 136-142.

Kaplan S.W.1984. The association between the sea anemone $M e$ tridium senile (L.) and the mussel Mytilus edulis (L.) reduces predation by the starfish Asterias forbesii (Desor). J. Exp. Mar. Biol. Ecol. 79: 155-157. http://dx.doi.org/10.1016/0022-0981(84)90216-8

Kenneth R., Anthony N., Svane I. 1995. Effects of substratum instability on locomotion and pedal laceration in Metridium senile (Anthozoa: Actiniaria). Mar. Ecol. Prog. Ser. 124: 171-180. http://dx.doi.org/10.3354/meps124171

Lewis J., Coutts A. 2010. Biofouling invasions. In: Dürr S., Thomason J. (eds), Biofouling. Wiley and Blackwell, Oxford, pp. 348-365.
López Gappa J.J., Romanello E.E., Hernández D.A. 1982. Observaciones sobre la macrofauna y flora asociadas a los grampones de Macrocystis pyrifera (L.) C. Ag. en la ría Deseado (Santa Cruz, Argentina). Ecosur 9: 67-106.

Martin J.P. Bastida R. 2008. El alga invasora Undaria pinnatifida (Harvey) Suringar en la Ría Deseado (Patagonia austral, Argentina): ciclo del esporofito y factores ambientales determinantes de su distribución. Rev. Biol. Mar. Oceanogr. 43: 335-344. http://dx.doi.org/10.4067/S0718-19572008000200011

Martin J.P., Cuevas M. 2006. First record of Undaria pinnatifida (Laminariales, Phaeophyta) in Southern Patagonia, Argentina. Biol. Inv. 8: 1399-1402. http://dx.doi.org/10.1007/s10530-006-0004-7

Martin, J.P., Bastida R., Ieno E. et al. 2000. Estudio sobre el biofouling de los humedales del estuario del Río de La Plata (Argentina). Thalassas 16: 54-65.

Nelson M.L., Craig S.F. 2011. Role of the sea anemone Metridium senile in structuring a developing subtidal fouling community. Mar. Ecol. Prog. Ser. 421: 139-149. http://dx.doi.org/10.3354/meps08838

Orensanz J.M., Schwindt E., Pastorino G., et al. 2002. No longer the pristine confines of the world ocean: a survey of exotic marine species in the southwestern Atlantic. Biol. Inv. 4: 115-143. http://dx.doi.org/10.1023/A:1020596916153

Otaegui A. J., Zaixso H. 1974. Distribución vertical de los moluscos marinos del litoral rocoso de la ría de Puerto Deseado (Santa Cruz, Argentina). Una guía para reconocer los diferentes pisos y horizontes litorales. Physis 33: 321-334.

Piriz M., Casas G. 1994. Occurence of Undaria pinnatifida in Golfo Nuevo, Argentina. Appl. Phycol. Forum 10: 4-4.

Rico A., López Gappa J. 2006. Intertidal and subtidal fouling assemblages in a Patagonian harbor (Argentina, Southwest Atlantic). Hydrobiologia 563: 9-18 http://dx.doi.org/10.1007/s10750-005-1337-4

Riemann-Zürneck, K. 1975. Actiniaria des Südwestatlantik. II. Sagartiidae und Metridiidae. Helgolander wiss. Meeresunters. 27: 70-95. http://dx.doi.org/10.1007/BF01611687

Ringuelet R.A., Amor A., Magaldi N., et al. 1962. Estudio ecológico de la fauna intercotidal de Puerto Deseado en febrero de 1961 (Santa Cruz, Argentina). Physis 23: 35-53.

Sar A. 2010. Distribución batimétrica, demografía y producción de Mytilus edulis platensis, en la Bahía de San Julián, Patagonia. Master's thesis, Universidad de Magallanes, 94 pp.

Schwindt E. 2007. The invasion of the acorn barnacle Balanus glandula in the south-western Atlantic 40 years later. J. Mar. Biol. Ass. U.K. 87: 1219-1225. http://dx.doi.org/10.1017/S0025315407056895

Sebens K.P. 1986. Community ecology of vertical rock walls in the Gulf of Maine, USA: small-scale processes and alternative community states. In: Moore P.G., Seed R. (eds), The Ecology of Rocky Coasts. Columbia University Press, New York, pp. 346-371.

Servicio de Hidrografía Naval (S.H.N). 2009. Tablas de Marea de Puerto San Julián. http://www.hidro.gov.ar/oceanografia/Tmareas/Form Tmareas.asp

Shick J.M. 1991. A Functional Biology of Sea Anemones. Chapman \& Hall, London, 395 pp. http://dx.doi.org/10.1007/978-94-011-3080-6

Sibly R., Calow P. 1982. Asexual reproduction in Protozoa and invertebrates. J. Theor. Biol. 96: 401-424 http://dx.doi.org/10.1016/0022-5193(82)90118-7

Theisen B.F. 1972. Shell cleaning and deposit feeding in Mytilus edulis L. (Bivalvia). Ophelia 10: 49-55. http://dx.doi.org/10.1080/00785326.1972.10430101

Wahl M. 1997. Living attached: Aufwuchs, Fouling, Epibiosis. In: Nagabhusanam R. (ed.), Fouling organisms of the Indian Ocean. Biology and control technology. CRC Press, Rotterdam, pp. 31-84.

Zaixso H.E. 1975. Distribución vertical de los moluscos marinos de la ría Deseado (Santa Cruz, Argentina) sustrato con fracción limosa. Physis 34: 229-243.

Zaixso H. E., Pastor C.T. 1977. Observaciones sobre la ecología de los mitílidos de la ría Deseado. I. Distribución y análisis biocenótico. Ecosur 4: 1-46.

Zamponi M.O., Acuña F. H. 1991. Zoogeografía y algunos aspectos ecológicos de la fauna de anémonas de la Provincia Magallánica. Neotrópica 37: 95105

Zar J.H. 1996. Biostatistical analysis. Prentice Hall, New Jersey, $718 \mathrm{pp}$. 